\title{
The Agreement of Suvalkai in the Context of Lithuanian Neutrality
}

\section{Česlovas LAURINAVIČIUS}

Thus far Lithuanian historians have not carried out any detailed investigation of the Agreement of Suvalkai. Nevertheless, it remains one of the most notorious events in Lithuanian history and is associated by Lithuanians with Poland's most serious "crime" against their land. Strong opinions have been voiced concerning the fact that hardly two days after the agreement had been concluded, Poland broke it and seized Vilnius, the capital of Lithuania ${ }^{1}$. Yet a closer look at the text of the break gives rise to a number of questions. For instance, how should one understand the word "broken" if Vilnius had been seized by the Polish troops a day before the agreement came into force? Or, why did the demarcation line, drawn from the Prussian border, end at Bastūnai, although the armistice zone did not stretch that far? In Lithuanian studies it would be hard to discern what the logic behind the demarcation line was. Despite the concerted opinion that this line had left Vilnius on the Lithuanian side, a historical atlas reveals that this assessment of the line is puzzling.

Similar uncertainties will keep arising as long as the Agreement of Suvalkai is viewed solely in the context of the PolishLithuanian conflict. But the veil of mystery rises as soon as a third factor - Russia - enters the context. Yet this involves a shift in accepted interpretations - "crime" becomes "tragedy". This may be the reason why a deeper analysis of this problem kept being delayed...

Naturally, the opinions of historians did not hide the fact that the history of the Suvalkai agreement testifies to the problematic character of the modern independent Lithuanian state. In the course of history, the Lithuanian state had long been associated by treaty with Poland. But since the latter half of the 19th century, there has been a tendency to dissociate Lithuania from Poland. The Polish reaction was as follows: it was asserted that by breaking away from Poland, under concrete geopolitical circumstances Lithuania would merely expand Russian or German territories. Moreover, Lithuanian ambitions were labelled as an intrigue of Russia or Germany. The idea of Lithuania's independence emerged as a kind of response to such speculations. It was moral, legitimate, logical. Its implementation be-

${ }^{1}$ Lietuvos istorija, red. A. Šapoka, Vilnius, 1989, 560-562; V. Daugirdaitè-Sruogienè, Lietuvos istorija, Vilnius, 1990, 323-324; Lietuvos TSR istorija, 3, Vilnius, 1965, 106-107. 
gan in 1918. But in the status quo of 1920 the possibility of implementing that ideal was tightened by a strict imperative of neutrality. Therefore it would be reasonable to view the Agreement of Suvalkai in the context of the possibilities of Lithuania's neutrality.

\section{The Outlines of the Background}

Analysing Lithuanian-Polish relations after World War I, researchers are faced with obscurities and ambiguities. For example, it is not clear on what grounds the Polish army occupied Vilnius and other former territories of the Grand Duchy of Lithuania in the spring of 1919. Was it the right of Poland to the historic land of the Republic of the Two Nations, i.e. the right of a part to the whole, or temporary authorization for Poland to push bolshevism back as far to the East as possible, or was it the realization of the intention to restore the Polish agreement with Lithuanians? The latter interpretation could be supported by the disasters connected with Pilsudski's famous proclamation to the citizens of the GDL, published at Vilnius in Polish and Lithuanian, after the Polish troops had expelled Bolsheviks from the city $^{2}$. However, agreement was not reached. Unable to find a satisfactory dialogue, Poland resorted to measures to undermine the Lithuanian government in Kaunas, and the latter, in its turn, was determined, using aid from Germany or elsewhere, to take Vilnius from Poland. Thus, a latent focus of military tension sprang up to the west of Vilnius.

The ambiguous situation in Eastern Europe was connected with the unclear position of the Entente. France had already raised the criterion of the 1772 frontiers that would orient towards the restoration of the state of affairs before the Polish-Lithuanian partitions. But Great Britain and the USA were inclined to consider the frontiers of 1914 as the starting point. To Poland, as well as Lithuania, this evoked the reminiscences of the Congress of Vienna (1815). Although after the Bolshevik coup d'état there were no longer any legal representatives of Russian affairs, it was a well-known fact that all Russian provisional governments, even though not opposing the restoration of Poland, were drafting its eastern borders from the boundaries of Vistula provinces. On August 29, 1918 the Bolsheviks had issued a statement concerning the annulment of all acts of partition and this would favour the situation in 1772. But the turn of events in 1918-1919 revealed only the Bolsheviks' desire to bring the Polish government to the negotiation table. On December 8, 1919 the Supreme Council of the Entente delineated a temporary eastern border for Poland which was not much different from the borders of the Vistula provinces: Poland acquired the provinces of Białystok and Bielsk and was deprived of the northern, Lithuanian-inhabited part of the Suvalkai province (gubernia). Nevertheless, this was already a different kind of demar-

${ }^{2}$ Č. Laurinavičius, Aus der Geschichte des provisorischen litauischen Komitees von Wilna (April bis Juni 1919), Nordost-Archiv, Neue Folge Bond, 11/1993, Heft. 2, 361-375. 
cation. This line virtually separated ethnographic Lithuania, including Vilnius, from Poland; only it is not clear whether this was done in order to consolidate the Entente's position of Lithuania and seek a compromise with Poland, or to leave the former for Russia. As Poland and Lithuania did not come to an agreement, a situation arose into which sooner or later a third party had to intervene.

In spring 1920 Poland launched an offensive in an attempt to dispossess the Soviets of territories gained by Russia in 1772, namely part of the Ukraine. But the Entente did not support this move. In the meantime, the Lithuanian government sent a delegation to Moscow and opened peace negotiations with Soviet administration. The latter did not conceal that it was inclined to recognize Lithuania including Vilnius. Before long, rumours were heard in Europe that Lithuanian troops in collaboration with the Red Army were staging an offensive in the direction of Vilnius. And although the Lithuanian government denied those rumours, it did not deny its ambitions to reclaim Vilnius.

Early in July 1920, as the Red Army started a violent attack in the West, Poland faced a real threat not only to its historic territories but also to its very independence. The Allies who until then had been passively watching the course of developments, decided to intervene for the sake of peace. Lloyd George, the British Prime Minister, considered Vilnius the most sensitive place in the conflict. At the conference in Spa (Belgium) he advised the Polish Prime Minister, W.Grabski, to cede Vilnius to Lithuania and withdraw the Polish troops behind the line of December 8. As Grabski tried to object, Lloyd George explained that Poland did not have the means to defend Vilnius - that pearl of the Polish culture in the East - from the Bolsheviks; judging by the course of negotiations in Moscow, Vilnius would become a Lithuano-Soviet Russian affair. If Poland should cede Vilnius to Lithuania, hope would remain that the Red Army would not seize the city; hence the Entente would get involved in the solution of the Vilnius problem which, in its turn, would open a possibility to take into account the rights of Poles in Vilnius too.

After Grabski had accepted the proposal, Lord Curzon sent a note to Moscow offering his mediation in the peace talks: the Red Army was to stop $50 \mathrm{~km}$ from the Dünaburg - Grodno railway and the line of December 8. Realizing that Vilnius - and indeed all Lithuania was slipping from its grip, the Soviet government hastily signed a treaty with the Lithuanian delegation on July 12 . Under this treaty a great deal of territory including Vilnius, was assigned to Lithuania. However, the appendix to this treaty stipulated that the Soviets obtained the right to occupy that territory and hence to cross the Curzon Line $^{3}$. This kind of appendix had not been planned by the Lithuanian

${ }^{3}$ Dokumenty vneshnei politiki SSSR [DVP], III, Moskva, 1959, 28-42. The appendix read as follows: "Since the Russo-Polish war is under way, since Poland is occupying a part of Lithuania which is stipulated by this truce, since the Red Army is incapable of stopping hostilities at the Lithuanian border, the signatories declare that the fact of the Red Army's 
government; it appeared after the Soviets had used more than mere diplomatic pressure on the Lithuania. In addition, the Lithuanian government had not expressed its approval of the Spa proposal. Meanwhile, after the Red Army occupied Vilnius, the organization of a communist coup began ${ }^{4}$. In effect this represented a consistent implementation of the "Lithuania-Russia" formula.

As they began preparing a major attack on Poland, and most probably also out of a desire to appease the Lithuanian government, the Soviets agreed to sign a peace convention (on August 6), which provided for the withdrawal of Red Army troops from Lithuania in three stages ${ }^{5}$. But the defeat at Warsaw forced the Soviets to make more drastic changes to their plans. Preparations for a communist coup in Lithuania were interrupted, the Red Army was hurriedly evacuated from Vilnius; the only remaining occupied territory was the so-called third evacuation zone along the Grodno-Lida railway.

In the meantime, Lithuanian units occupied the southern part of the Suvalkai province as far as the Augustowo Canal and were stationed next to the Red Army in Grodno. Such was the situation when late in August the Polish army approached Grodno.

\section{The Suvalkai Period}

On August 27, the Lithuanian Minister of Foreign Affairs, Juozas Purickis, sent a note to his Polish counterpart, Eustace Sapieha, to the effect that in the war between Poland and Soviet Russia, Lithuania "as previously would adhere to strict neutrality" (continuera d'observer la stricte neutralité). As a means to avoid a conflict between Lithuania and Poland, it offered the demarcation line Sztabin - Augustowo - Grabów ${ }^{6}$.

A note containing such comments ought to have been a shock. First, it was not clear how "strict neutrality" could be reconciled with the presence of the Red Army in a territory recognized as Lithuanian (in the Grodno - Lida zone) with the approval of Lithuania. One more aspect is puzzling: Sztabin, where the Lithuanian border, drawn by the Moscow Treaty, ended, was located on the western frontier of the Grodno gubernia (province) - slightly further to the west than the line of December 8. The Purickis demarcation line drawn from Sztabin appeared to be a tacit proposal on the Lithuanian (and Soviet Russian) side for Poland to "return" to the

overstepping the Lithuanian border and occupying a part of its territory will not be considered a violation of this truce or an act unfriendly to Lithuania". According to Chicherin's explanation in his note of July 16 to Purickis, the "annexe was inseparable from the truce" (for further details, see: Č.Laurinavičius, Lietuvos-Rusijos taikos sutartis, Vilnius, 1992, 143-156.)

${ }^{4}$ A.E. Senn, The Great Powers. Lithuania and the Vilna Question 1920-1928, Leiden, 1966, 31-35.

${ }^{5}$ DVP, III, 1959, 86-89.

${ }^{6}$ Documents diplomatiques. Conflict polono-lithuanien. Question de Vilna. 1918-1924, Kaunas, 1929, 45. 
Vistula provinces. And this was the time when Poland had used tremendous efforts to recover the Poznan territory from Germany and had repelled the Bolsheviks from Warsaw! On the other hand, it was a proof that Lithuania (and Soviet Russia) did not recognize the line of December 8.

Nevertheless, the concept of neutrality in Purickis' note threw a different light on Lithuania from the one expressed by the Moscow Treaty, and Poland had to take this into account.

On August 27, the Polish Defence Council discussed the state of affairs. It took into consideration the incitement of the Allied countries to Poland not to cross over the line of December 8 and to avoid conflict with Lithuania. The decision was made to overstep the line of December 8 with respect to Russia (probably as a result of an agreement made from P. Wrangel's administration). But the Lithuanian question was singled out. According to prevailing opinion, it was necessary to compromise with Lithuania.

It is worth noting that there is not clear by now that decision was made on the Lithuanian question. According to a collection of documents published in Moscow in 1967, the Council decided: a) in Suvalkija, to restore the line of December 8 , using force if necessary; b) to occupy the territories that the Soviets had recognized as Lithuanian $^{7}$ (consequently, the occupation of Vilnius was possible). However, the protocol of the same meeting, published in Warsaw in 1967, is formulated in a different way: a) in Suvalkija - to demand recognition of the line of December 8 . In case of refusal - to take the territory by force; b) in the Bolshevik-occupied territories - to have a free hand ${ }^{8}$ (hence, the Grodno-Lida zone was borne in mind).

Poland's implemented actions were also controversial. Already on August 26 a Polish military delegation arrived in Kaunas and held talks until August 30. One of the Polish proposals to Lithuania looked acceptable: in Suvalkija the Lithuanian army should withdraw behind the line of December 8 and should guard the northern edge of the Red Army's third evacuation zone on the right bank of the Nemunas; as Poland launched an offensive in the direction of Grodno-Lida, the Red Army troops were not to gain an opportunity to reach the Poles' rear via Lithuanian-controlled territory'. Therefore, this plan meant that Poland was inclined not to infringe on territory Lithuania actually governed, including Vilnius.

A difficulty arose over Suvalkija. The removal of the Lithuanian army from the occupied territory could be regarded by the Soviets as a violation of neutrality. The problem, however, did not look unsolvable because Purickis had already agreed to send a political delegation to Warsaw.

${ }^{7}$ Dokumenty i materialy sovetsko-polskich otnoshenij, III, Moskva, 1967, 340.

${ }^{8} \mathrm{~A}$. Leinwand, J. Molenda, Protokoly Rady Obrony państwa, $Z$ dziejów stosunków polsko-radzieckich, $I, 1965,271$.

${ }^{9} \mathrm{~J}$. Urbšys, Medžiaga Vilniaus ginčo diplomatinei istorijai, Kaunas, 1932, 21-23. 
Yet the Polish army, without awaiting the outcome of negotiations, was struggling towards the line of December 8 . It also began to see that the Lithuanian-occupied Suvalkija served as a transit to Russia from Prussia for the Red Army troops, defeated at Warsaw. The reaction of the Lithuanian government was weak. Poland was accused of aggression, its delegates - of espionage (they were hurriedly declared "personae non gratae"). The Lithuanian leaders were even more infuriated by Sapieha's note of August 31 in which the December 8 line was provocatively identified with the so-called marschal Fosch line (July 18,1919$)^{10}$. Those lines coincided only on the left bank of the Nemunas, while on the right bank the Fosch line rose northward along the Grodno-Dünaburg railway, leaving Vilnius on the Polish side.

On September 2 the Lithuanian army at Suvalkija launched a counterattack and regained its former positions.

It seems that Great Britain approved of such actions on the Lithuanian side. On September 3, a report arrived from the Lithuanian attaché in London: "The best way to secure an effective intervention of the Entente will most probably be an armed opposition to the Polish aggression. This commitment is fully understood here. Tiškus"11. There are grounds to believe that London was thinking about new efforts on the part of the great powers to intervene in the settlement of the conflict.

The Soviet position was also interesting. On September 4, Chicherin announced to Kaunas in his radio address that in connection with the new conflict between Lithuania and Poland, "it is necessary to define Lithuanian-Russian relations in military matters". Chicherin went on to say that "if the Lithuanian government gives us a guarantee that its territory is inviolable, and that it can prevent Poland from capturing it, the Russian administration is ready to pledge itself to withdraw from Lithuanian territory". Chicherin asked for a prompt reply ${ }^{12}$.

In principle, Chicherin's note to Lithuania could have been an important document in the legal defence of its territory. It meant that, under certain conditions, the Soviets could renounce the formula Lithuania-Russia. These, however, were only outlines of the idea, especially since, in effect, it was very important to know what territory was considered to be Lithuanian: was Lithuania able, without an infringement of its territorial inviolability, to withdraw its army beyond the December 8 line? Judging by the statements of other Soviet representatives, Lithuania should in no way accept the line in question. And on September 5 the Chief Military Commissar Leo Trotsky ordered the Red Army to "repel the Poles on Lithuanian territory"13.

${ }^{10}$ Documents diplomatiques..., 46.

${ }^{11}$ LCVA, f. 383, ap.7, b.74, 1.134. The Lithuanian representative in London at this time was Alfred Tyszkiewicz.

${ }^{12} \mathrm{DVP}$, III, 1959, 165. 
On September 5, Sapieha accused Lithuania publicly of nonobservance of neutrality and of co-operation with the Red Army in the territory recognized as Polish. It appealed to the League of Nations for intervention to prevent an armed conflict between Poland and Lithuania $^{14}$. According to P.Lossowski Sapieha wanted to save this appeal as a way of saving time until the Polish army was ready to attack. According to Lossowski, this was a mistake on Poland's part, too, since the intervention of the League of Nations would restrict the actions of Poland ${ }^{15}$. There is, however, reason to believe that "on Poland's part" Sapieha's move should not to be viewed as a mistake. This opinion could be supported by the telegram sent by the Lithuanian representative in London to Kaunas on September 8: "The intervention of the League of Nations... has brought ... complications ... Curzon is to decide tomorrow whether the British government will propose a conference in London, or inform the League of Nations, where we are going to be summoned according to article 17. Therefore I advise you not to allow any further conflict until the Poles cross the line (of December 8)"16.

Here, perhaps, it is necessary to explain that the conference, convened by the Allied countries, and the League of Nations is not the same thing. The Allies were responsible for arranging the face of Europe's post-war politics. They had also created the League of Nations whose function was to settle conflicts within the limits of existing agreements.

But the Allied countries remained the essential guarantors of order. Whereas the League of Nations - if it was a guarantor at all was more of a last than a first resort. Hence, on the basis of Sapieha's note the transfer of the Lithuanian-Polish dispute to the League of Nations (with an alternative of a special Entente conference) should have increased and not reduced the possibilities of the Polish initiative.

From September hostilities in Suvalkija were resumed. And they were rather serious. Lithuania suffered heavy losses. On September 9-10 the Polish army reached the December 8 line. Poland went on to insist that the Lithuanian government should publicly recognize that line. In his note of September 12 Purickis actually expressed approval for this ${ }^{17}$. This fact served as a basis to refrain from hostilities, and resume the Lithuanian-Polish talks.

Yet nothing positive came of Kalvarija negotiations (September 15-17). Right on the eve of the truce the Lithuanian army staged a

${ }^{13}$ Pravda, 196, 05.04.1920.

${ }^{14}$ Documents diplomatiques..., 69-70. It is worth noting that in his note Sapieha was not asking to solve the fundamentals of the Polish-Lithuanian dispute. No mention of Vilnius was made (see: A.E. Senn, op. cit., 37).

${ }^{15}$ P. Łossowski, Stosunki polsko-litewskie w latach 1918-1920, Warszawa, 1966, 236, 262.

${ }^{16}$ LCVA, f. 383 , ap. 7 , b. $74,1.130$.

${ }^{17}$ Documents diplomatiques..., 50-51. 
new offensive on towards Seinai which naturally could not but influence the Polish position. At Kalvarija the Poles issued an ultimatum to recognize the December 8 line. The Lithuanian delegation refused in order, as it seemed to the Poles, to win time. Having stated this, the Polish representatives announced that the truce of September 18 was cancelled $^{18}$.

One way or another this turn of events confirms the view that the Lithuanian position was really affected by rumours about the launching of a new offensive by the Red Army as well as by the provocative arrival of Trotsky in Lida right before the start of Kalvarija negotiations $^{19}$

There is one more fact worth noting in this context. On September 16 the Lithuanian government issued a declaration "A propos the Territories Recovered from Occupation" under which the territory recognized Lithuanian by the Moscow Treaty was to be annexed on general grounds. Discussing the Declaration, the Seim rejected the unreal suggestions of some deputies a plebiscite to hold in Eastern Lithuania. But on the other hand, the declaration passed by the Seim in point of fact sanctioned the "relithuanization" of those territories ${ }^{20}$. Although in the West and of course in Poland such a Lithuanian measure could be recognized as little more than the formula Lithuania Soviet Russia.

Meanwhile on September 16-20 the Council of the League of Nations in Paris was discussing the Polish-Lithuanian conflict in Suvalkija. The Polish representative, I.Paderewski. maintained the traditional demand that Lithuania observe the line of December 8 , while the Lithuanian spokesman, A.Voldemaras, was trying to prove that Lithuania was not bound by the line of December 8 as it had neither taken part in establishing this line nor had been informed of it. The treaty signed by Russia and Lithuania supposed a demarcation line different from the one of December 8 . Therefore the line set down by the Moscow treaty ought to be taken as a basis for the settlement, Voldemaras believed. Moreover - and here he quoted Chicherin's note of September 4 - the Soviets were ready to withdraw from the entire territory recognized as Lithuanian.

Having heard the statements of both sides, the Council declared that what was being expected of it was not the "ultimate solution of the dispute but just the demarcation of occupation zones", since bilateral talks were in progress which would obviously have to deal with the most essential problems. The Council was aware that negotiations were being held in Kalvarija but the outcome of these talks was still unknown. Solving its task, the Council based its decision on "capitally important" circumstance that a war between Poland and

${ }^{18}$ P. Łossowski, op. cit., 242-245.

${ }^{19}$ A.Ragauskas, Pilsudskis ir Lietuva, Naujienos, 196706 02; Trocky's telegram of 13.09.1930 to the Lithuanian Minister of Defence, LCVA, f. 384, ap. 3, b. 60, 1. 13-15.

${ }^{20}$ Lietuva, 166, 19200906. 
the Soviets was still going on and the part of Lithuanian territory was still occupied by the Red Army. According to the Council, the latter circumstance "reduces the possibility of Lithuania's preventing Poland from using Lithuanian territory for military needs" and complicates the drawing of a demarcation line between Lithuania and Poland. Nevertheless, "regarding Lithuania's wish to be neutral" (underlined - C.L.) the Council passed the following resolution on September 20: Lithuania, reserving its territorial rights, withdraws beyond the line of December 8 , and Poland, also reserving its own territorial rights, respects the neutrality of the occupied Lithuanian territory lying east of the line of December 8 on the condition that this neutrality is also respected by the Soviets. The Council was to establish a special commission to oversee the implementation of the resolution ${ }^{21}$.

Thus the resolution of the Council of the League of Nations passed on September 20 dealt only with the issue of a temporary demarcation line between the Polish and Lithuanian armies. But Voldemaras understood this resolution as the recognition by both the League of Nations and Poland of Lithuanian territory as defined by the Treaty of Moscow. On September 21 he telegraphed to Kaunas: The Poles agree ... to respect Lithuania's neutrality within the limits of the Curzon Line and the Lithuanian border set by the Treaty of Moscow, from the place it intersects with the Curzon Line, if the Russians will respect the neutrality of this area". Voldemaras urged his government to ratify a solution of this kind and to demand that the Polish government do the same ${ }^{22}$. Yet Voldemaras did not indicate what the Lithuanian government should do in order to make the idea that the Soviets respect Lithuania's neutrality more effective.

It seems that until that time Kaunas had entertained certain doubts. The reason was that information was arriving from Riga concerning preparations for Polish-Soviet negotiations. Judging by the information from Dovas Zaunius, the British representative, $\mathrm{S}$. Tallents, the Latvian Foreign Minister and Z.Meierovic were taking certain steps for the arrangement of Polish-Lithuanian negotiations in Riga, too. Poland was not exactly charmed by such a perspective. But Zaunius himself advised his government not to hurry with the talks; it appeared that Joffe (leader of the Soviet delegation) had said that the Red Army would soon launch an offensive ${ }^{23}$.

It seems that the Paris alternative looked more reliable to the Lithuanian government. Voldemaras was telegraphed: "We agree to accept the basis for negotiations as proposed by Poland and ... to transfer the case to the League of Nations. It is important for us to reach a final agreement with Poland while they are fighting with the Russians... Purickis"24. Hence Lithuania agreed to submit to the arbi-

${ }^{21}$ Documents diplomatiques..., $72-74$.

${ }^{2}$ LCVA, f. 383, ap. 7, b. 142, 1. 146.

${ }^{23}$ D.Zaunius' reports from Riga: September 15 and 20, - ibid., 1. 143, 148.

${ }^{24}$ Puricki's undated draft of a telegram to Voldemaras in Paris - ibid., l. 144. 
tration of the League of Nations, hoping that the Lithuanian territory had already been recognized in accordance with the Moscow Treaty, whereas Poland accepted the resolution of September 20 somewhat cynically as being adequate... In fact, the League of Nations set down to the heart of the Lithuanian-Polish dispute only in the second half of October, 1920, that is after Želigowski's march to Vilnius. On September 22 its army began to attack the Lithuanian positions at Seinai, broke them, crossed the line of December 8 , traversed the Nemunas near Druskininkai and turned southward. It left the Lithuanian-controlled territory on September 24. It was a manoeuvre within a general Polish offensive aimed at driving the Red Army back from the Grodno-Lida line. The Red Army troops, sensing danger on its flanks, began to withdraw rapidly to the East; they were replaced by the Polish army.

As far as concerns Lithuania, this was a brutal provocation. But formally speaking the actions of Poland did not contravene the resolution of the Council of the League of Nations from September 20. The Chairman of the Council Leon Bourgeois simply reprimanded Poland for "not leaving time" for Lithuania to execute the resolution of December 8: to withdraw behind the line of December 8 and to obtain Soviet guarantees to respect Lithuania's neutrality ${ }^{25}$.

On September 25 in two radiograms to Paris and Kaunas, Chicherin made it clear that the Soviet government would agree to accept the resolution of the League of Nations on Lithuanian neutrality $^{26}$. It meant that Moscow was ready to set its right of initiative as regards Lithuania on the same footing as Polish rights in this regard. Yet as far as Lithuania was concerned, Moscow had other options. Having resumed peace talks with the Poles in Riga, the Soviets were at the same time suggesting that Lithuania should conclude a military alliance with them, when Lithuania refused, they declared, that they had a right to occupy Lithuanian territory (Chicherin's note of September 27) ${ }^{27}$. The Soviets had another option which was kept secret. Tension was growing.

As with the radiogram of September 4 the Lithuanian government once more failed to take a firm stand in response to Chicherin's radiogram of September 25. It also did not take pains to issue any statement in justification of its wish to the rights of Poland and the Soviets as regards Lithuania. To be more exact, this could have been a denial of the Soviets' right to the unilateral occupation of Lithuania. The Latvian proposal to act as a mediator in order to draw Lithuania into the Riga negotiations was received with scepticism. But Kaunas also refused to enter any military alliance with the Soviets. Hence, the

${ }^{25}$ Documents diplomatiques..., 76-77.

${ }^{26} \mathrm{DVP}$, III, 1959, 212.

${ }^{27}$ Ibid., 218. Chicherin's note of September 27 said: "since Lithuania does not accept a (military) alliance, we will have to guarantee our security ourselves, occupying in Lithuanian territory such points and lines as are necessary, pledging to withdraw from them immediately after the strategic necessity ceases to exist". 
Lithuanian government passively reconciled itself to the Soviet right to occupy Lithuania, i.e. in order tò defend itself against Poland. This Lithuanian diplomacy was based on the sophistical demonstrations. It would be obvious from the following telegram of P.Klimas to the embassy in London on September 29: "The Polish pretext for occupying Vilnius in order to attack the Bolsheviks poses danger to the whole of Lithuania. In that case, the Bolsheviks would ignore the treaty and attack ... as follows from Chicherin's note (September 27). This new Bolshevik occupation would be a direct result of Polish invasion. Thus we will have to fight this invasion to our last ....... Make every effort in order to protect Lithuania from this misfortune by diplomatic means" 28 . (my emphasis). Unfortunately, the logic of realia was quite different. In view of not providing any guarantees by Poland the above demonstrations means in fact just a special way of interpreting the "LithuaniaSoviet Russia" formula.

Meanwhile Lithuania concetrated its strength on expressing indignation at Polish activities (concerning the manoeuvres of September 22-24). Several members of the Constituent Assembly even appealed for a total national war against Poland. Understandably, the immediate weight of such hatred fell on the Lithuanian Poles. The opinion was forming in Lithuania that Poland had broken Lithuania's neutrality by depriving the Soviets of the occupied part of Lithuania. Hence the perception of neutrality was becoming inseparable in Lithuania from Soviet occupation.

We must make our own deductions as to how trust began to increase in the Polish camp. On September 26 Sapieha made a proposal to the Lithuanians to continue the broken negotiations at Kalvarija. The following day, despite the case being sub indice in the League of Nations, Purickis' deputy Petras Klimas agreed to negotiate without any stipulations. The talks at Suvalkai were attended, in fact, by observers from the Allied countries. There is, however, no evidence that those observers had any influence on the course or results of the negotiations. The talks were resumed on September 30 only now on the Polish territory - at Suvalkai. On this occasion the journal "Lithuania" wrote: "The Poles will have to take responsibility for violating our neutrality. These talks could be another Polish trick. But there are other factors: a) Lithuanian determination, b) the Polish-Russian negotiations are not smooth. The Russians have called up a lot of new forces..."29

\section{The Suvalkai Negotiations}

P.Lossowski believes that Poland needed the talks at Suvalkai only in order to gain time until preparations for the occupation of Vilnius had been concluded ${ }^{30}$. This view is not open to doubt. It can

${ }^{28}$ LCVA, f. 383 , ap. 7, b. 74, 1. 121.

${ }^{29}$ Lietuva, 211, 19200930.

${ }^{30} \mathrm{P}$. Łossowski, op. cit., 275-292. 
just be added that during the Riga talks Polish efforts were concentrated since late September on one demand: that the Soviets reject the Moscow treaty with Lithuania ${ }^{31}$.

And what was the Lithuanian position at that time? On September 27 the Lithuanian Cabinet of Ministers passed the following resolution on the Suvalkai negotiations: "The Lithuanian delegation can agree, defining the demarcation line between the Lithuanian and Polish armies, with the line of the so-called third zone as a maximum concession" 32 . It is unknown whether the Lithuanian delegation received any other instructions. But there are documents which throw light upon the course of the talks. They show that the Lithuanians continued to base their political future on the treaty of Moscow as they were assured that the Treaty was also binding on the other parties - the League of Nations and even Poland. We can see from the documents how views were changing.

Note Voldemaras' telegram of September 29 from Paris to Kaunas: "It was stated yesterday officially that Vilnius is in no danger. Immediately work out procedures for Polish withdrawal from Lithuania which conform to convention with the Bolsheviks. The League of Nations will guarantee that the Poles observe the treaty. The Control Commission ... is departing today. Polish tactics will be to avoid the Commission's mediation" ${ }^{33}$.

On September 30 Klimas telegraphed to Bronius Balutis, a member of the Lithuanian delegation in Suvalkai: "Voldemaras announced yesterday that the Poles suggested transferring the whole question to the League of Nations. You are not to negotiate with the Poles until they announce their submission to the League of Nations. Start from that point" 34 . However, the League of Nations' accounts show that the Control Commission was allowed to act only within the limits of the resolution of September 20. On the other hand, the talks at Suvalkai opened without the intercession of the League of Nations $^{35}$.

Here is the Lithuanian delegation's account of the first day of the negotiations: "We offered a truce along the whole front. The Poles willingly accept a truce in the Suvalkai province as this is no longer the arena of hostilities with Russia. On receiving knowledge of our note that we agree to withdraw behind the line of December 8 , the Poles expressed profound and great delight. They declared that now it will be easier to agree concerning the other side of the Nemunas where the questions are only military... Their tone seems to be quite different from that in Kalvarija..." ${ }^{36}$

${ }^{31}$ P. Wandycz, Soviet-Polish Relations 1917-1921, Cambridge, 1969, 262-270.

${ }^{32}$ LCVA, f. 923, ap. 7, b. 86, 1. 295.

${ }^{33}$ Ibid., f. 383, ap. 7, b. 162, 1. 130-131.

${ }^{34}$ Ibid., b. 80, 1. 153 .

${ }^{35}$ Documents diplomatiques..., 83-85; J.Urbšys, Medžiaga..., 40-42.

${ }^{36}$ LCVA, f. 383 , ap. 7 , b. $80,1.136-138$. 
On October 1, Klimas telegraphed to Suvalkai: "Curzon notes that the situation at present is such that it is necessary to agree over a demarcation line which will not have any political significance. Therefore they call for moderation... Insistance on a truce before the discussion of the demarcation line may not bear fruit... The line ought to be accepted in order to show the world our desire for peace, and to deprive the Poles of their arguments about our cooperation with Bolsheviks. England promises help in having the Poles withdraw from Lithuania as soon as there is peace between Poland and Russia. At the moment, a modus vivendi ought to be established... Should a proposal arrive to hold negotiations in Riga - say that this will be passed on to the authorities. It ought to be noted, however, that the entire Lithuanian-Polish dispute is now in the hands of the League of $\mathrm{Na}$ tions. There is not too much prospect from our talks in Riga, since we are going to be the weaker side there. The mediation of the League of Nations or someone else would possibly eliminate this element of greater power. Discussions held during the first meeting have produced a highly favourable impression"37.

But on the very same day, the battle over the control of the Varéna railway station which the Poles sought to take, began. The point was, that according to the Lithuanian General Staff's orders, Varéna was to serve as a transit point for the transfer of the troops from Suvalkija towards Vilnius. On October 1 Poles suggested a demarcation line from the Nemunas - Merkinè - Varéna Station (positions to be held by the Poles). On October 2 the talks were interrupted. The Lithuanian delegation made inquiries about Varéna and received the instruction: "not to cede the railway, since this would mean infringing our neutrality and would be tantamount to the conclusion of a treaty against Russia" ${ }^{38}$.

Eventually on October 3 the Lithuanian delegation proposed a demarcation line from the Nemunas - across Uciech - Bastūnai Ašmena - towards Iža ${ }^{39}$. This time the Poles asked for a truce. They travelled to Bialystok for Pilsudski's instructions. The latter permitted a demarcation line to be drawn extending no further than Bastūnai ${ }^{40}$.

In the evening the Lithuanian delegation received the announcement of Klimas' report that the Control Commission had arrived. Klimas advised it compromise only when forced by the Commission to do so. He went on to say: "In view of the fact that the Bolsheviks have already withdrawn from the whole of Lithuania, we need to formulate a clause to the effect that when the Poles make a truce with the Russians, the former immediately withdraw from Lithuania behind the line of December 8, i.e., behind the Nemunas and our borders fixed with Russia ${ }^{41}$.

${ }^{37}$ Ibid., 1. 127

${ }^{38}$ Ibid., 1. 145

${ }^{39}$ Protocoles officiels de conferences polono-lithuaniennes a Suvalki, Warszawa, 1921

${ }^{40}$ P.Łossowski, op. cit., 279-280.

${ }^{41}$ LCVA, f. 383 , ap. 7, b. 80, 1. 115. 
On October 4 the Klimas delegation seemed to have changed its mind: "If you see that the Commission reacts coolly, accept the line suggested by Poland. At the moment our situation is not such that we would be able to insist upon our wishes" ${ }^{42}$.

On its arrival on October 5, the Control Commission undertook to conclude a truce at Varena. Troops were halted at the place where they were stationed. The truce zone set out by the Commission extended from the Nemunas to Paturce. Meanwhile the delegations were drafting the text of the truce.

In the meantime, an agreement of principles was reached in Riga between Poland and Soviet Russia. The Polish negotiators demanded and obtained the territories to the east of the line of July 12, thus removing the Soviets' right to occupy Lithuania. The framework of the Moscow Treaty was destroyed. On October 6 Tomas Naruševičius telegraphed from Riga to Kaunas: "On Friday the ceasefire conditions were signed. The Poles obtain a corridor with Latvia... We do not have any frontiers with Russia... Save the situation via the League of Nations" ${ }^{43}$. Shortly afterwards news arrived from Suvalkai as well that the treaty had been signed.

On October 7 Klimas sent a telegram to the delegation in Suvalkai, which was to be the last: "It is very embarassing that the demarcation line has not been drawn to the east of Bastūnai... If they do not believe that the Bolsheviks are there - they can go there with the Allied representatives. Yesterday the Poles had already begun to march from Lida towards Vilnius. It does not matter that today it is quiet - there are no formal guarantees that tomorrow it will be the same. It is necessary to proceed with the talks. We should stick to a very soft tone, making pledges on our part to guarantee the Poles' rights in Lithuania and even the possibility of establishing close neighbourly relationship. Currently it is necessary to indicate a very sharp antagonism to the Poles because of the attacks made by their army. If they enter Vilnius - relations will be spoiled once and for all. If they leave us in peace - there will be a chance of a truce (my emphasis - compare with Klimas' arguments in his telegram of September 29). Such is the tone. Tomorrow a truce will be signed in Riga. Poland is gaining the Vileika-Disna corridor. We are totally separated from Russia. Such is the situation" 44 .

In the turn of events we have discussed, we see a certain repetition of the situation that supposes a possibility of Lithuania's neutralization. The first moment is the resolution of the Spa Conference and the Treaty of Moscow, the second - the negotiations in Kaunas of the late August; the third moment - between Chicherin's radiogram of

${ }^{42}$ Ibid., 1. 135

${ }^{43}$ Ibid., b. $76,1.18$. On October 5 an engagement was signed in Riga to conclude a preliminary truce on October 8 . The signing was delayed until October 12 "for technical reasons".

${ }^{44}$ Ibid., b. $80,1.118$. 
September 4 and negotiations at Kalvarija, the fourth - between Chicherin's radiogram of September 25 and the Suvalkai negotiations. In all those four moments one can observe the rapprochement of three agents - the Entente, Poland and Soviet Russia - over the issue of Lithuania's neutrality. Understandably, the attitudes of all the three agents in specific cases remain uncertain - these require special research. One common tendency, however, can be defined, namely: inconsistency. However, on the part of the Allied countries this found expression in passivity, and on the part of Poland and Soviet Russia in aggression.

A higher degree of definiteness can be stated with regard to the Lithuanian position - in all above-mentioned instances it did not serve neutrality.

In the first case it had not shown any initiative for the Spa resolutions and had chosen the solution of the Vilnius problem according to the formula Lithuania-Soviet Russia.

In the second case, although Lithuania had met Poland with a declaration of strict neutrality, it practically remained within the limits of the aforesaid formula.

In the third case, Lithuania relied more on Trotsky's order to the Red Army than on the possibilities offered by Chicherin's radiogram of September 4.

In the fourth case, a tendency became apparent in Lithuania to identify the peacemaking initiative of the League of Nations with approval for the formula Lithuania-Soviet Russia. It was expected that the League of Nations would force Poland to withdraw from Lithuanian territory as defined by the Treaty of Moscow, therefore, even during the Suvalkai negotiations, no haste was made to draw the demarcation line - i.e. to bestow the status of least preliminary neutrality to the territory that was in fact governed by Lithuania. Thus one ought to note the insufficiency of Lithuanian political maturity, which would be specifically symbolized by the line of the Suvalkai Treaty in the atlas.

However, the situation should not be simplified without recourse to the broader context. Analysing the developments of the summer and autumn, 1920, two tendencies can be observed: a) the Lithuanian ambition, on the basis of the Russian factor, to expel Poland from the historical territories of the Grand Duchy of Lithuania; the climax of this ambition was the Moscow Treaty of July 12, 1920; and b) the Polish goal to sever Lithuania from Russia, which was achieved on October 5, 1920 by the treaty of Riga.

There could be analogies to these tendencies, for instance, in Czechoslovakia's aim of reaching Russia across the Transcarpathian zone and the desire of Poland and Hungary to prevent this.

Therefore in this case we would be dealing with manifestations of panslavism which determined the political face of Europe in the 20 th century and... a reaction against them. Faced with forces of 
such magnitude, it would not seem surprising that somewhere in Kaunas Lithuanian diplomats were not quite adequately reading one or another resolution; even so, one could have hoped that matters would be settled in the desired trend.

Nevertheless, the experience of history shows that free determination is inseparable from responsibility. This was also unavoidable in Lithuania's desire to become neutral. In the geopolitical situation of 1920 Lithuanian neutrality would have meant a compromise between the above-mentioned powerful tendencies. It is doubtful whether this was at all possible. However, in any case, the historical atlas bears its mark - known as the line of the Agreement of Suvalkai.

In conclusion it should be noted that after Polish troops had occupied Vilnius, the history of the Aggreement of Suvalkai was not over. But that would be a story not of Lithuania's neutrality, but of something quite different. 